\title{
Maternal Effects on Reciprocals for Some Yield and Yield Components in Upland Cottons (Gossypium Species L.)
}

\author{
S.Y. Simon ${ }^{1}$ A.M. Kadams And S.J. Louis \\ ${ }^{1,2}$ Department of Crop Production and Horticulture ModibboAdama University of Technology, Yola
}

\begin{abstract}
Crosses were made between eight cotton genotypes in a full diallel crossing pattern in 2005/2006 at the $R$ esearch farm of the School of Agriculture and Agricultural Technology, Yola. The resulting 56 F1 hybrids along wit $h$ their parents were evaluated in the cropping seasons of 2007 and 2008 at Yola, Adamawa State and Sibre, Tarab a State, Nigeria in a Randomized Complete Block Design (RCBD) with three replications. The study investigated th e reciprocal and maternal effects on the parents and reciprocal crosses; SAMCOT $8 \times$ SAMCOT 9, TAMCOTCAMD -E $x$ EX-Benin and SAMCOT $13 \times$ SAMCOT. SAMCOT 12 was the maternal parent that showed the highest matern al effect for yield and yield components, which could be said to be responsible for the phenotypic expression of the $r$ eciprocals.
\end{abstract}

Key words:Maternal effects, hybrids, cotton, reciprocal effects and yield components

\section{Introduction}

Cotton research especially in the area of genetics is very vital in order to increase the yielding ability of loc ally developed cotton varieties, which will make them very attractive and profitable to farmers so as to stimulate inte rest in cotton production. The need for more adapted high yielding varieties cannot be overemphasized especially $\mathrm{w}$ ith the expansion of the textile industry in Nigeria. Emphasis therefore needs to be placed on the cotton breeding so as to enhance its utilization significantly. Spore (2009) have reported that breeding progress for increased yields has greatly decreased in recent years therefore, there is the need for more breeding work to improve the cotton plant. $\mathrm{H}$ owever, genetic improvement can only be achieved when genetic information about any particular genetic materials is readily available, which the plant breeder can utilize and exploit to achieve fast genetic improvement. It is exactly this derive to enhance the yielding ability of Nigerian cotton, to international standards, that this study is being prop osed with the following objectives.

Maternal effects have been genetically evaluated and analysed in animals as well as plants that show norma 1 reciprocal cross differences (Jinks et al. 1972; Mather and Jinks, 1982; Falconer, 1989). Maternal effects arise whe re the mother makes contribution to the phenotype of her progeny above that which results from the genes she contri butes to the zygote. Maternal effect results in the production of difference between reciprocal crosses which are shar ed between the offspring of both sexes in all the generations where they occur. Maternal effects also lead to a greate $r$ resemblance of the progeny to the maternal parent. In hermaphroditic species, maternal effects can be detected by making crosses reciprocally between pairs of individuals irrespective of whether they are homozygous or heterozygo us. However, the breeding history of the individuals should be known in order to make a useful biometrical analysis and interpretations (Mather and Jinks, 1982). Jinks et al.(1972), discussed in details the analysis and interpretation of differences between reciprocal crosses using Nicotianarustica varieties. He noted that reciprocal differences coul $\mathrm{d}$ either be transient when there are differences in the maternal environment or persistent, which arise through unequ al contribution of cytoplasmic determinant from the female and male gametes to the zygote.

Sometimes the early growth and development of the zygote is so much influenced by the surrounding mater nal tissue that the progeny very much resemble the female parent. However, by raising the subsequent generations, maternal effect, extra chromosomal inheritance or maternal inheritance is suspected when a significant difference is detected in reciprocal crosses (Sinha and Sinha, 1980). But unlike maternal effect, the differences caused in materna 1 inheritance do not usually disappear after one generation. This research was therefore carried out with the followin g objective:

1. To estimate maternal effects on reciprocals

\section{Materials And Methods}

The study was conducted in two locations in Yola, Adamawa State (Lat. $7^{\circ} 11^{1} \mathrm{~N}$ and Long. $11^{\circ} 14^{\prime} \mathrm{E}$ ) and $\mathrm{t}$ he other at Sibre Village in Ardo-Kola Local Government Area in Taraba State (Lat. $6^{\circ} 30^{\prime}$ and $9^{\circ} 36^{\prime} \mathrm{N}$ and Long $9^{\circ} 1$ 
$\left.5^{\circ} 50^{1} 10^{\prime} \mathrm{E}\right)$. In Adamawa State, the site was in Yola which is located at Lat $9^{\circ} 18^{\prime}$ Long, $12^{\circ} 15^{\prime} \mathrm{E}$ and has an altitud e of $200 \mathrm{~cm}$ above sea level and is within the Northern Guinea Savannah zone. The soil type is clay loam. While the location in Taraba State, is within the sub-sudan vegetation zone, located at longitude $8^{\circ} .30^{\prime}-9^{\circ} 00^{\prime} \mathrm{N}$, latitude $11^{\circ}$. $00^{\prime}-11^{\circ} .30^{\prime}$ East of Jalingo, the Taraba State capital. It has a temperature range of $30^{\circ} \mathrm{C}-36^{\circ} \mathrm{C}$ during the rainy seaso n. The soil is loamy to sandy loam.

\section{Biometrical procedures:}

The maternal interaction (According to Edwards and Emara, 1970) is analysed as follows; $\partial_{\mathrm{g}}^{2}=\left(\partial_{\mathrm{m}}^{2}+\partial_{\mathrm{j}}^{2}\right)=\partial_{\mathrm{g}}^{2}+\partial_{\text {mat }}^{2}$

$\partial^{2}{ }_{\mathrm{s}}=\partial_{\mathrm{mf}}^{2}=\partial_{\mathrm{s}}^{2}+\partial_{\mathrm{r}}^{2}$ where;

$\partial_{\mathrm{g}}^{2}=$ maternal component, $\quad \partial_{\mathrm{s}}^{2}=$ non - additive variance component

$\partial_{\mathrm{r}}{ }^{\mathrm{g}}=$ maternal interaction $\quad \partial_{\mathrm{m}}^{2}=$ additive maternal effect

\section{Estimates of maternal effects of parents}

\section{Results}

The estimates of maternal effects are presented in Table 1. The result showed that SAMCOT 11 is the mate rnal parent that had highest maternal effect on the phenotypic expression of the reciprocal as it positive maternal eff ects seven characters namely; for days to first flowering, days to boll opening, boll size, number of bolls per plant, li nt percentage, seed yield and lint yield. SAMCOT 12 second as it had maternal effect on six characters followed by EX-Benin with maternal effect on five and SAMCOT 13 which had positive effect on four characters. Only SAMC OT 9 and SAMCOT 8 had maternal effect on two characters each while the remaining did not have any maternal eff ect on the phenotypic expression of any of the characters except SAMCOT 10 that had effect on plant height

\begin{tabular}{|c|c|c|c|c|c|c|c|c|c|c|c|c|}
\hline $\mathrm{S} / \mathbf{n}$ & $\begin{array}{l}\text { Maternal } \\
\text { Parent }\end{array}$ & Parental lines & $\begin{array}{l}\text { Days to } \\
\text { First } \\
\text { Flowering }\end{array}$ & $\begin{array}{l}\text { Days to } \\
50 \% \\
\text { flomering }\end{array}$ & $\begin{array}{l}\text { Days to } \\
\text { boll } \\
\text { opening }\end{array}$ & $\begin{array}{l}\text { Plant } \\
\text { height } \\
(\mathrm{m})\end{array}$ & $\begin{array}{l}\text { Boll } \\
\text { size } \\
(\mathrm{cm})\end{array}$ & $\begin{array}{l}\text { No of } \\
\text { bolls } \\
\text { plant }\end{array}$ & $\begin{array}{c}\text { Lint } \\
\%\end{array}$ & $\begin{array}{l}\text { Seed } \\
\text { yield } \\
(\mathrm{g})\end{array}$ & $\begin{array}{l}\text { Lint } \\
\text { xield } \\
(\mathrm{g})\end{array}$ & $\begin{array}{l}\text { Days to } \\
\text { maturity }\end{array}$ \\
\hline 1. & MAT 1 & SAMCOT 8 & -3.052 & -0.465 & -6.031 & 3.850 & -1.170 & -4.996 & -0.621 & -5.501 & 0.482 & 12.062 \\
\hline 2. & MAT 2 & SAMCOT 9 & -0.092 & -0.059 & -9.026 & 2.504 & 0.037 & -1.884 & -0.402 & -8.921 & -0.578 & 7.584 \\
\hline 3. & MAT 3 & SAMCOT 10 & -0.608 & -0.487 & -10.605 & 1.418 & -0.642 & -1.199 & -0.216 & -4.509 & -0.248 & 1.226 \\
\hline 4. & MAT 4 & TAMCOTCAMD-E & -0.112 & 0.358 & -5.219 & 0.208 & -0.158 & -0.682 & 0.247 & -3.073 & -0.596 & -4.627 \\
\hline 5. & MAT 5 & SAMCOT 13 & 0.788 & 1.788 & 3.225 & -1.806 & -0.120 & 3.144 & 0.169 & 2.982 & -0.226 & -3.419 \\
\hline 6. & MAT 6 & EX-BENIN & 0.855 & 0.538 & 8.468 & -2.729 & -0.341 & 2.198 & 0.229 & 5.275 & 0.235 & -5.468 \\
\hline 7. & MAT 7 & SAMCOT 11 & 1.137 & 0.682 & 11.925 & 1.268 & 2.204 & 3.239 & 0.232 & 5.783 & 0.701 & -5.720 \\
\hline \multirow[t]{2}{*}{8.} & MAT 8 & SAMCOT 12 & 1.082 & 1.643 & 7.263 & -4.715 & -0.809 & 0.181 & 0.361 & 7.965 & 1.232 & -1.635 \\
\hline & & $\mathrm{SE}$ & 0.021 & 0.34 & 2.01 & 1.20 & 0.41 & 0.75 & 0.03 & 2.46 & 0.34 & 5.12 \\
\hline
\end{tabular}

\section{Maternal effects on reciprocals}

\section{Discussions}

Jinks et al. (1972) discussed in detail the analysis and interpretation of differences between reciprocal cross es using Nicotianarustica varieties. He noted that reciprocal differences could either be transient when there are diff erences in the maternal environment or persistent, which arise through unequal contributions of cytoplasmic determi nants from the female and male gametes to the zygote. From the result obtained in this study. SAMCOT 11 which $\mathrm{s}$ howed significant positive maternal effects for days to first flowering, days to boll opening, boll size, number of boll $\mathrm{s}$ per plant, lint percentage, seed and lint yield as well as significant negative effect for days to maturity, can be said t o be responsible for the phenotypic expression of most of these characters, followed by SAMCOT 12, EX-Benin and SAMCOT 13. Interestingly, these maternal parents are also among the parents with good general combining ability. Jinks et al (1972); Mather and Jinks, (1982) and Falconer, (1989), reported that maternal effects results in the produ ction of differences between reciprocal crosses which are shared between the offspring of both sexes in all the gener ations where they occur. Aliyu, (2001) therefore concluded that maternal effects also leads to a greater resemblance of the progeny to the maternal parent. Significant maternal effect tends to inflate the variances due to females, and $h$ ence the variance components.

Generally, from the results obtained, it is clear that the effects of the maternal parents on the expression of $t$ he reciprocals ranged from significant to non significant. This means that there may be differences in the maternal e nvironment which according to Jinks et al. (1972), could arise through unequal contributions of cytoplasmic determi nants from the female and male gametes to the zygote. Gardner and Snustard (1981) reported that sometimes the ear ly growth and development of the zygote is so much influenced by the surrounding maternal tissue that the progeny 
very much resemble the female parent. However, Sinha and Sinha, (1980) cautioned that, by raising subsequent gen erations, maternal effects, extrachromosomal inheritance or maternal inheritance is suspected when a significant diff erence is detected in reciprocal crosses. However, Mather and Jinks, (1982) suggested that the breeding history of th e individuals should be known in order to make a useful biometrical analysis and interpretation.

\section{References}

[1]. Aliyu, B. (2001). Inheritance of pubescence and genetic compatibility between cowpea (vignaunguiculata (L) Walp.) and V. rhomboidea Burtt. Davy. Ph.D Thesis, University of Ibadan, Nigeria.

[2]. Edwards, K.J.R. and Emara, Y.A (1970). Variation in plant development within a population of Liliummultiflorum, Heredity, 25: 179-1 94

[3]. Falconer, D.S (1989). Introduction to quantitative genetics. $3^{\text {rd }}$ ed. Longman scientific and technical, Essex, England.

[4]. Gardner, E.J., and D.P. Snustad, (1981). Principles of Genetics. John Willey. 510p

[5]. Jinks, J.L., J.M. Perkins and S. Gregory, (1972). The analysis and interpretation of difference between reciprocal crosses of Nicotianarus ticavarieties. Heredity.26:363-377.

[6]. Mather, K and J.L. Jinks, (1982). Biometrical Genetics: The study of continuous variation. Longman, London 396 P.

[7]. Sinha, U. and S. Sinha (1980). Cytogenetics, plant breeding and Evolution. Vikas Publishing House, PVT, Sahibabad, India. 408p

[8]. Spore, (2009). Food crises; Tackling price instability. No. 143:8-9 